\title{
KEEFEKTIFAN PENGGUNAAN MEDIA BRETTSPIEL DALAM KETERAMPILAN BERBICARA BAHASA JERMAN SISWA KELAS X SMA NEGERI 11 MAKASSAR
}

\author{
Andi Tenri ${ }^{1}$, Wahyu Kurniati Asri, ${ }^{2}$, Laelah Azizah ${ }^{3}$ \\ Fakultas Bahasa dan Sastra, Universitas Negeri Makassar
}

Email ${ }^{1}$ : anditenri621@yahoo.com

\begin{abstract}
ABSTRAK
Penelitian ini dilakukan untuk memeroleh data dan informasi mengenai keterampilan berbicara bahasa Jerman siswa dengan media Brettspiel.Penelitian ini adalah penelitian Quasi-eksperimen yang pengumpulan datanya melalui tes keterampilan berbicara.Data dianalisis dengan uji-t. Populasi penelitian adalah siswa kelas X yang berjumlah 132 siswa dari tujuh kelas. Sampel dalam penelitian dipilih secara. Data dianalisis menggunakan analisis Uji-t. Hasil penelitian menunjukkan bahwa $t_{\text {hitung }} 6,16>t_{\text {tabel }} 2,042$ pada taraf signifikan 0,05. Hasil analisis data menunjukkan bahwa media Brettspiel efektif dalam keterampilan berbicara siswa kelas X SMA Negeri 11 Makassar.
\end{abstract}

Kata Kunci: Media Brettspiel, Keterampilan Berbicara, dan Bahasa Jerman.

\begin{abstract}
This study was conducted to obtain data and information about German language speaking skill of students by using Brettspiel media. This research is a Quasiexperimental. Data collection used test speaking skill. Data were analyzed by t-test. The study population was students of class X who consist of 132 students from seventh grade. The samples were selected by using random. Data were analyzed using t-test analysis. The results showed that thitung 6.16> ttable 2,042 on significant level of 0.05 . The result showed that the Brettspiel media is effective in increasing speaking skill of students in class X SMA Negeri 11 Makassar.
\end{abstract}

\section{Keywords: Brettspiel Media, speaking skill, and German Language}

\section{PENDAHULUAN}

Mengingat pentingnya bahasa sebagai alat komunikasi, maka di berbagai lembaga pendidikan di Indonesia telah diajarkan berbagai bahasa mulai dari bahasa daerah, bahasa Indonesia sebagai bahasa nasional sampai bahasa asing. Salah satu bahasa asing yang telah diajarkan di Sekolah Menengah Atas (SMA) yaitu bahasa Jerman.
Penelitian ini difokuskan pada kompetensi keterampilan berbicara karena berbicara merupakan keterampilan komunikasi bagi manusia yang dapat mengungkapkan ide, gagasan, isi pikiran, dan pesan, baik secara tertulis maupun lisan. Berbicara dan mendengarkan merupakan komunikasi secara langsung karena itu dalam kehidupan ini keterampilan berbicara sangat dibutuhkan. 
Masalah tersebut perlu dicari solusi dengan memanfaatkan media yang tepat misalnya dengan menggunakan berbagai macam variasi media dalam proses belajar mengajar untuk meningkatkan keterampilan berbicara bahasa Jerman. Salah satu media yang bisa digunakan adalah Brettspiel.

Media tersebut digunakan karena diharapkan mampu menimbulkan kegembiraan dan dapat menambah kosakata siswa. Selain itu media tersebut dapat dimanfaatkan sebagai pengusir kebosanan saat siswa mulai tampak lesu mengikuti pelajaran bahasa Jerman dan pada akhirnya siswa akan tertarik untuk menuangkan ide, gagasan dalam berbicara bahasa Jerman. Media Brettspiel berfungsi untuk memudahkan siswa dalam memahami arti tentang suatu kata, sehingga siswa dapat menggunakan kata-kata tersebut sesuai dengan maknanya secara kontekstual.Permainan dalam media ini juga dapat memupuk rasa solidaritas terutama untuk permainan bahasa biasanya mengesankan sehingga sukar dilupakan.

Berdasarkan hasil observasi dan wawancara dengan guru bahasa Jerman SMAN 11 Makassar diperoleh informasi bahwa siswa masih mengalami kesulitan dalam berbicara bahasa Jerman, terutama dalam mengungkapkan gagasannya. Salah satu faktor yang menyebabkan hal tersebut adalah sikap dan minat siswa dalam mengikuti pembelajaran berbicara rendah. Pada umumnya siswa merasa takut dan malu saat ditugasi untuk tampil berbicara di depan teman-temannya serta siswa kurang terampil sebagai akibat dari kurangnya latihan berbicara. Sedangkan dalam silabus dikatakan bahwa siswa harus dapat mengungkapkan informasi secara lisan dalam bentuk paparan atau dialog sederhana tentang identitas dirinya.

Ada beberapa penelitian tentang keterampilan berbicara yang pernah dilakukan antara lainTahang (2013:95) menunjukkan bahwa keterampilan berbicara bahasa Jerman siswa kelas XI IPA 1 SMA Negeri Pinrang termasuk dalam kategori sedang dengan hasil (87,5\%). Penelitian yang sama dilakukan oleh Juwita (2016:48), hasil penelitian tersebut mengungkapkan bahwa keterampilan berbicara bahasa Jerman siswa kelas Xl IPA SMAN 11 Makassar termasuk dalam kategori sedang dengan hasil (88,3\%), sedangkan penelitian tentang Brettspiel yang dilakukan Prastiyani (2013:214) menunjukkan bahwa penguasaan dalam keterampilan membaca bahasa Jerman siswa kelas XI SMA N 1 Sedayu Bentul dalam kategori sedang dengan hasil (77,44\%). Sehubungan dengan hal tersebut, maka perlu diadakan penelitian dengan judul Keefektifan Penggunaan Media Brettspiel dalam Keterampilan Berbicara Bahasa Jerman Siswa Kelas X SMAN 11 Makassar. 


\section{MEDIA BRETTSPIEL}

Media konvensional sudah sering dan sudah lama digunakan dalam dunia pendidikan. Pemakaian media konvensional secara terus menerus akan menimbulkan suasana belajar yang monoton. Lama kelamaan peserta didik akan merasa bosan dan perhatian serta konsentrasi peserta didik terhadap materi pelajaran pun akan berkurang. Hal ini akan berdampak pada motivasi belajar peserta didik yang akan memberikan kontribusi pada menurunnya hasil atau prestasi belajar peserta didik. Sehingga media Brettspiel diharapkan mampu menjadi media baru yang dapat membantu jalannya proses belajar mengajar agar dapat mencapai tujuan pembelajaran seperti yang diharapkan.

Menurut Arsyad (2009:3) media pembelajaran Brettspiel adalah seluruh alat yang dapat menciptakan kondisi yang memungkinkan pembelajar untuk menerima pengetahuan, keterampilan dan sikap, media ini merupakan media permainan

Pada pembelajaran media Brettspiel siswa diberikan kesempatan bertanya dan menjawab melalui permainan Brettspiel, namun sebelum penerapan media tersebut pengajar terlebih dahulu memperhatikan aturan permainan media Brettspiel. Adapun aturan permainan media Brettspiel sebagai berikut: Prastiyani (2013:51) menjelaskan tentang aturan dalam permainan media Brettspiel. Permainan media Brettspiel biasanya berlangsung kurang lebih 20 menit.
Permainan dapat berlangsung lebih lama atau lebih pendek, disesuaikan dengan jumlah tugas atau pertanyaan yang diberikan. Permainan ini melibatkan 2 orang pemain atau 2 kelompok yang berlawanan.

Dari pendapat di atas, dapat disimpulkan bahwa aturan permainan media Brettspiel adalah sebagai berikut: (1) Siswa dibentuk dalam kelompok, (2) Guru mempersiapkan perlengkapan permainan, (3) Siswa memulai dengan cara membacakan pertanyaan yang telah disediakan untuk lawan mainnya, (4) Permainan berlangsung terus sampai pertanyaan atau tugas habis, (5) Kelompok yang mempunyai Spielkarte warna paling banyak adalah pemenangnya.

\section{KETERAMPILAN BERBICARA}

Berbicara adalah suatu kegiatan yang dilakukan seseorang atau sekelompok orang yang mengucapkan untuk menyetakan dan mengekspresikan pemikiran, gagasan kepada sekelompok orang kepada para penggemar. Tarigan (2008:16) berpendapat bahwa berbicara adalah kemampuan mengucapkan bunyibunyi artikulasi atau kata-kata yntuk mengekspresikan, menyatakan serta menyampaikan pikiran, gagasan, dan perasaan.

Keterampilan berbicara adalah salah satu kompetensi berbahasa untuk mengucapkan kata-kata, bunyi artikulasi untuk mengungkapkan pendapat, pikiran, dan perasaan kepada seseorang atau sekelompok secara lisan baik secara berhadapan ataupun jarak jauh. Di bawah ini 
dikemukakan pendapat beberapa ahli tentang keterampilan berbicara yaitu:

Tarigan (2008:3) menjelaskan bahwa berbicara adalah suatu keterampilan berbahasa yang berkembang pada kehidupan anak, yang didahului oleh keterampilan menyimak, dan pada masa tersebutlah keterampilan berbicara atau berujar dipelajari.

Abidin (2013) menyatakan ada empat tujuan pembelajaran keterampilan berbicara di sekolah yaitu: 1) membentuk kepekaan siswa terhadap sumber ide, 2) membangun kemampuan siswa mnghasilkan ide, 3) melatih kemampuan berbicara untuk berbagai tujuan, dan 4) membina kreativitas berbicara siswa.

\section{METODE PENELITIAN}

Penelitian ini terdiri dari dua variabel yaitu variabel bebas dan variabel terikat. Penggunaan media Brettspiel sebagai variabel bebas (X), sedangkan keterampilan berbicara siswa sebagai varibel terikat (Y). Penelitian ini menggunakan Quasi Eksperimental dengan bentuk design pretest-posttest Control Group Design. Dalam penelitian ini melibatkan dua kelompok yaitu kelas eksperimen yang menggunakan media Brettspiel dan kelas kontrol menggunakan metode Konvensional dalam keterampilan berbicara bahasa Jerman siswa kelas $X$ SMAN 11 Makassar.

Untuk menghindari terjadinya salah penafsiran mengenai variabel dalam penelitian ini, peneliti memperjelas definisi operasional variabel yang dimaksud.

Media Brettspiel merupakan salah satu media yang menggunakan papan sebagai bahan ut ama dalam permainannya.Papan yang digunakan bisa bisa berupa papan kayu, papan yang berasal dari kertas karton atau papan yang dibuat dari bahan kertas tebal. Dalam pelaksanaannya media Brettspiel memerlukan perlengkapan sebagai berikut:

1. Spielbrett berupa papan dari kayu, kertas karton, kertas tebal atau bahkan dari kertas biasa yang berwarna putih.

2. Fragekarten berupa kartu-kartu yang berisi pertanyaan atau tugas yang berwarna merah.

3. Spielsteine/Spielkarten kartu yang berbeda warna untuk kelompok yang berlawanan. Kelompok A berwarna kuning dan kelompok B berwarna hijau.

Keterampilan berbicara adalah kemampuan berbahasa siswa dalam berkomunikasi, menuangkan ide dan gagasannya yang berkaitan dengan brettspiel yang akan diajarkan. Penelitian ini akan menggunakan tes kemampuan tingkat penerapan (C3). Tes ini akan dinilai dari cara siswa menerapkan kemampuan berbahasa Jerman dalam sebuah permainan papan (brettspiel). Tema yang akan dijadikan sebuah permainan ialah Kennenlernen.

Populasi dalam penelitian ini adalah kelas X SMAN 11 Makassar yang terdiri atas 7 kelas dengan jumlah keseluruhan siswa adalah 132 siswa. Penetapan sampel yang 
digunakan dalam penelitian ini adalah sampel acak (random sampling). Dari populasi, terpilih kelas secara acak yaitu kelas X.3 sebagai kelas eksperimen yang terdiri atas 16 siswa dan kelas X.7 sebagai kelas kontrol yang terdiri atas 16 siswa sebagai sampel penelitian.

Pengumpulan data yang akan dilakukan dalam penelitian ini adalah dengan menggunakan sebuah instrumen yaitu tes kemampuan berbicara. Tes yang akan digunakan adalah sebuah berikut:

1. Tes Awal (Pretest) adalah tes yang dilakukan sebelum diberi perlakuan. Tes ini akan diberikan kepada kedua kelompok untuk mengukur tingkat penguasaan keterampilan berbicara siswa.

2. Tes Akhir (Posttest) adalah tes yang dilakukan setelah mendapatkan perlakuan. Tes ini akan diberikan kepada kedua kelompok dengan tema Kennenlernen. Tes ini digunakan untuk mengetahui perbedaan tingkat penguasaan keterampilan berbicara yang menggunakan media brettspiel dan tanya jawab.

Data yang diperoleh dari test keterampilan berbicara siswa dianalisis dengan menggunakan rumus uji-t. Teknik analisis data dalam penelitian ini adalah analisis statistika inferensial untuk menguji hipotesis penelitian dengan menggunakan analisis uji-t. Namun, sebelum dilakukan pengujian hipotesis terlebih dahulu dilakukan uji normalitas, dan uji homogenitas dengan menggunakan tabel Z- score dan chi kuadrat, sebelum menentukan uji normalitas data dan homogenitas maupun uji hipotesis terlebih dahulu tentukan nilai rata-rata (mean), simpangan baku dan varian.

\section{PEMBAHASAN}

Pada penelitian ini, pembelajaran dilakukan selama empat kali pertemuan setelah pemberian pre-test di kedua kelas. Pada kelas eksperimen siswa menggunakan media Brettspiel, sedangkan kelas kontrol menggunakan pembelajaran konvensional.

Sesuai dengan hasil pre-test siswa di kelas X.3 sebagai kelas eksperimen menunjukkan bahwa nilai rata-rata (mean) keterampilan berbicara siswa adalah 59,4 dan masih dikategori cukup yang nilai tertingginya ialah 75 dan nilai terendahnya ialah 42. Berdasarkan data distribusi frekuensi dan persentase, nilai yang paling banyak diperoleh oleh siswa ialah nilai antara 63-69 sebanyak 5 siswa atau 31,25\%.

Hasil pre-test siswa di kelas X.7 4 sebagai kelas kontrol menunjukkan nilai rata-rata (mean) keterampilan berbicara siswa adalah 42,75 dan nilainya dikategori kurang yang nilai tertinggi adalah 67 dan nilai terendah adalah 8. Berdasarkan data distribusi frekuensi dan persentase, nilai yang paling banyak diperoleh siswa adalah nilai antara 44-55 sebanyak 6 siswa atau $37,5 \%$.

Berdasarkan hasil post-test siswa di kelas X.7 sebagai kelas kontrol menunjukkan nilai rata-rata (mean) keterampilan berbicara siswa 
adalah 65,69 dan nilainya dikategori cukup yang nilai tertinggi adalah 83 dan nilai terendah adalah 50 . Berdasarkan data distribusi frekuensi dan persentase, nilai yang paling banyak diperoleh siswa adalah nilai antara 64-70 sebanyak 9 siswa atau $56,25 \%$.

Dari hasil post-test kelas kontrol di atas menunjukkan bahwa nilai rata-rata siswa masih di bawah nilai KKM. Hal ini disebabkan oleh metode pembelajaran yang digunakan guru tidak bervariasi (monoton), serta hanya mengacu pada satu buku yaitu buku Deutsch ist einfach dan jarang menggunakan media belajar seperti media audio dalam proses pembelajaran. Selain itu, pendekatan pembelajaran yang dilakukan di kelas masih berpusat pada guru, hal ini terlihat pada saat peneliti melakukan observasi yaitu guru menjelaskan materi dalam buku, kemudian memberikan tugas yang ada pada buku kepada siswa.

Sebelum dilakukan pengujian hipotesis, terlebih dahulu dilakukan pengujian normalitas data. Dalam pengujian normalitas, data yang diambil ialah data nilai pre-test siswa di kelas eksperimen dan kelas kontrol. Pengujian ini dilakukan untuk melihat apakah data yang diperoleh normal atau tidak.

Pada uji normalitas data posttest masing-masing kelas menunjukkan hal yang sama yaitu pada kelas eksperimen chi-kuadrat hitung lebih kecil dari chi-kuadrat tabel, $X_{\text {hitung }}<X_{\text {tabel, }} \quad(-70,10<9,49)$ sehingga distribusi datanya dinyatakan normal. Begitu pula pada kelas kontrol chi-kuadrat hitung lebih kecil dari chi-kuadrat tabel, $X_{\text {hitung }}$ $<X_{\text {tabel, }} \quad(2,18<9,49) \quad$ sehingga distribusi datanya dinyatakan normal.

Hasil analisis di atas, dilanjutkan dengan uji-t untuk melihat hasil akhir dari penelitian ini, masingmasing kelas dengan rumus yang sama. Hasilnya adalah thitung kelas eksperimen $=6,16$ sementara $t_{\text {tabel }}=$ 2,042 , jadi $t_{\text {hitung }} \geq t_{\text {tabel }} \quad(6,16 \geq$ 2,042).

Maka dari itu, dapat disimpulkan bahwa, $\mathrm{H}_{1}$ yang menyatakan bahwa Penggunaan media Brettspiel efektif dalam pembelajaran keterampilan berbicara bahasa Jerman siswa kelas X SMAN 11 Makassar dinyatakan diterima $\mathrm{H}_{0}$ yang menyatakan bahwa Penggunaan media Brettspiel tidak efektif dalam pembelajaran keterampilan berbicara bahasa Jerman siswa kelas X SMAN 11 Makassardinyatakan ditolak. Oleh karena itu, dapat disimpulkan bahwa penelitian tentang keefektifan penggunaan media Brettspiel dalam keterampilan berbicara bahasa Jerman siswa kelas X SMA Negeri 11 Makassar dinyatakan berhasil.

Temuan penelitian ini yaitu media Brettspiel efektif dalam keterampilan berbicara bahasa jerman siswa kelas X SMA Negeri 11 Makassar. Sejalan dengan teori yang dikemukakan Prastiyani (2013 : 53) media Brettspiel dapat digunakan untuk berbagai macam materi, permainnya hanya terdiri atas dua orang atau dua kelompok kecil dan waktu yang digunakan untuk 
melaksanakan permainan ini tidak lama sehingga tidak menghabiskan banyak waktu.

\section{KESIMPULAN}

Berdasarkan hasil analisis data yang telah diuraikan pada bab IV di atas, dapat disimpulkan bahwa penggunaan media Brettspiel efektif dalam pembelajaran keterampilan berbicara bahasa Jerman siswa kelas X SMA Negeri 11 Makassar. Hal tersebut dibuktikan dari hasil analisis uji-t pada nilai post-test siswa setelah dilakukan uji-t pada masing-masing kelompok dengan hasil analisis data yaitu $t_{h}=6,16>t_{t}=2,042$ pada taraf signifikansi 0,05 yang berarti bahwa peningkatan yang signifikan setelah penggunaan media Brettspiel dalam pembelajaran dimana $t_{h}$ lebih besar daripada $t_{t}$. Ini menunjukkan bahwa penggunaan media Brettspiel efektif dalam keterampilan berbicara bahasa Jerman siswa kelas X SMA Negeri 11 Makassar.

\section{DAFTAR PUSTAKA}

Abidin, Yunus. 2013. Pembelajaran Bahasa Berbasis Pendidikan Karakter. Bandung: PT Refika Aditama.

Angkowono, R dan A. Kosasih. 2007.Optimalisasi Media Pembelajaran. Jakarta: PT. Grasindo.

Ardiansyah, Sulabdi. 2014. Keterampilan Berbicara Bahasa Jerman Siswa Kelas XI IPA SMA Negeri Makassar. Skripsi. FBS: UNM.
Arsyad, Azhar. 2009. Media Pembelajaran. Jakarta : PT. Raja Grafindo Persada.

Arsyad, Azhar. 2014. Media Pembelajaran. Jakarta: Rajawali Pers.

Ampa, A.P., Basri, M dan Andriani, A.A. 2013. The Development Of Contextual International Journal of Education An Research. 1 (9).

Bolton, Silbylle. 1991. Problem der Leistung München: Goethe Institut Langendscheid.

Bosch, Robert. 2004. Im Sprachunterricht spielen? Aber Ja!. München: Herstellung J. Gotteswinter $\mathrm{GmbH}$.

Dauvillier, Christa, Dorothea LévyHillerich. 2004. Spiele im Deutschunterricht. Berlin: Goethe Institut.

Djiwandono, Soenardi. 2011. Tes Bahasa Pegangan Bagi Pengajar Bahasa. Jakarta: Indeks.

Iskandarwassid \& Sunendar, D. 2013. Strategi Pembelajaran Bahasa. Bandung: PT Remaja Rosda Karya.

Juwita. 2015. Keefektifan Media Puzzle Picture Dalam Keterampilan Berbicara Bahasa Jerman Siswa Kelas XI IPA SMAN 11 Makassar. Makassar : UNM

Kurniawati, Heti. 2006. Penggunaan Media Brettspiel 4 Gewinnt Dalam Pengajaran Bahasa Jerman. http:// dc225. 4shared. com. doc/ eHAmJuec/ preview_html. 
Di unduh pada tanggal 18 Juni 2016.

Maywald, $\quad$ Anke. 2009 Profesionalisierung sozialer Arbeit durch Qualitätsmanagement Eine Studie. Hamburg: Diplomatica Verlag.

Musfiqon, HM. 2012. Pengembangan Media dan Sumber Pembelajaran. Jakarta: PT. Prestasi Pustakaraya.

Neuner, Gerhard. 2006. Fertigkeit Sprechen. München: Manuela Beisswenger, Mechtild Gerdes.

Nurjamal, Daeng. Dkk. 2011. Terampil Berbicara. Bandung: Alfabeta.

Nurjamal, Daeng. 2013. Terampil Berbicara.

Bandung:Alfabeta.

Prastiyani. 2013. Keefektifan Penggunaan Media Brettspiel 4 Gewinnt Dalam Pembelajaran Keterampilan Membaca Teks BahasaJerman Peserta Didik Kelas Xi Sma Negeri 1 Sedayu Bantul. Yogyakarta: UNY.

Rai, I Gusti Agung. 2008. Audit Kinerja pada Sektor Publik. Jakarta: Salemba Empat.

Sanaky, Hujair AH. 2009. Media Pembelajaran. Yogyakarta: Safiria Insania Press.

Steinig, Wolfgang dan Huneke HansWerner. 2011. Sprachdidaktik Deutsch. Berlin. Erich Schmidt Verlag.

Sudjana, 2005. Metode Statistika, Edisi 6. Bandung: tarsito.
Sugiyono. 2011. Metode Penelitian Pendidikan Pendekatan Kuantitatif, Kualitatif, dan $R \& D$. Bandung: Alfabeta.

Sugiyono. 2013. Metode Penelitian Kuantitatif, Kualitatif, dan $R$ $\& D$. Bandung: Alfabeta.

Supardi. 2013. Aplikasi Statistika dalam Penelitian. Jakarta: Smart.

Tahang, Hidayat. 2013. Penerapan Model Pembelajaran Kooperatif Tipe Co-op Coop dalam Meningkatkan Keterampilan Berbicara Bahasa Jerman Siswa Kelas XI IPA 1 SMA Negeri 1 Pinrang.Skripsi. Makassar : UNM

Tarigan, Henry Guntur. 2008. Berbicarasebagai suatu keterampilan berbahasa. Bandung: Angkasa. 